\title{
PENERAPAN PRINSIP BUSINESS JUDGMENT RULE TERHADAP DIREKSI YANG MELAKUKAN KEBIJAKAN YANG MERUGIKAN PERUSAHAAN
}

\author{
Robin Panjaitan, Martono Anggusti, Roida Nababan \\ Fakultas Hukum, Universitas HKBP Nommensen \\ martonoanggusti@uhn.ac.id
}

\begin{abstract}
Abstrak
Penelitian ini ditujukan untuk memahami penerapan business judgement rule pada direksi yang menjalankan fungsi pengurusan Perseroan dan Perlindungan Hukum terhadap direksi dalam pengurusan perusahaan melakukan kebijakan yang merugikan perusahaan dikaitkan pada Undang-Undang No. 40 Tahun 2007 tentang Perseroan Terbatas. Penelitian ini merupakan penelitian yuridis normatif dengan metode pendekatan penelitian terhadap pendekatan perundang-undangan. Sumber data berdasarkan data primer, sekunder dan tersier yang dianalisis secara yuridis deskriftif. Hasil penelitian menunjukkan bahwa penerapan Business Judgement Rule memberikan perlindungan hukum bagi direksi dan pejabat perseroan dari pertanggungjawaban atas setiap kebijakan atau keputusan bisnis atau transaksi yang mengakibatkan kerugian bagi perseroan, selama kebijakan atau keputusan bisnis atau transaksi tersebut dilakukan dengan itikad baik, penuh kehati-hatian, serta dalam lingkup tanggung jawab dan wewenangnya...
\end{abstract}

\section{Kata Kunci : Penerapan Prinsip Business Judgment, Kebijakan Yang Melakukan Perusahaan}

\begin{abstract}
This study is aimed at understanding the application of business judgment rules to directors who carry out the management function of the Company and legal protection for directors in managing the company to carry out policies that are detrimental to the company as related to Law No. 40 of 2007 concerning Limited Liability Companies. This research is a normative juridical research with a research approach to the statutory approach. Data sources are based on primary, secondary and tertiary data which are analyzed juridically descriptive. The results show that the application of the Business Judgment Rule provides legal protection for the directors and company officials from liability for any policies or business decisions or transactions that result in losses to the company, as long as the policies or business decisions or transactions are carried out in good faith, with great care, as well as within the scope of responsibility and authority.
\end{abstract}

Keywords: Application of the Principles of Business Judgment, Policy That Performs the Company. 


\section{PATIK : JURNAL HUKUM Vol : 10 No. 1 April 2021, Hal 1 - 14}

\section{Pendahuluan}

Pancasila, UUD1945, NKRI dan Bhinneka Tunggal Ika diakui sebagai Empat Pilar berbangsa dan sebagai tonggak dalam bernegara di Indonesia. Tujuan Penjelasan perekonomian pada Pasal 33 UUD1945 yang terbagi dalam beberapa ayat menerangkan bahwa: ayat (1)Perekonomian disusun sebagai usaha bersama berdasar atas asas kekeluargaan; ayat (2) Cabang-cabang produksi yang penting bagi negara dan yang menguasai hajat hidup orang banyak dikuasai oleh negara; ayat (3) Bumi dan air dan kekayaan alam yang terkandung di dalamnya dikuasai oleh negara dan dipergunakan untuk sebesar-besar kemakmuran rakyat; (4) Perekonomian nasional diselenggarakan berdasar atas demokrasi ekonomi dengan prinsip kebersamaan, efisiensi berkeadilan, berkelanjutan, berwawasan lingkungan, kemandirian, serta dengan menjaga keseimbangan kemajuan dan kesatuan ekonomi nasional; ${ }^{1}$ ayat (5) Ketentuan lebih lanjut mengenai pelaksanaan pasal ini diatur dalam undang-undang. Pasal 33 menjelaskan bahwa sistem campuran, yaitu sistem yang mengatur keseimbangan antara peran negara dan swasta dalam kegiatan bisnis dan ekonomi. ${ }^{2}$

Proses Perkembangan Indonesia menghadapi berbagai tantangan dan rintangan ketika belum tuntas menghadapi berbagai masalah globalisasi, sepertiperubahan gaya hidup yang bersifat individualis, pragmatis, konsumtif dan lunturnya nilai budaya asli kemudian muncul Era Revolusi Industri 4.0 yang bersifat tren otomasi dalam segala hal dan dilengkapi dengan masalah pandemi covid-19yang memberikan perubahan cara hidup baru, sepertiphysical distancing, hindari keramaian, sering cuci tangan dengan sabun, pakai masker, work from home ${ }^{3}$. Indonesia pada saat ini sebagainegara berkembang berkewajiban untuk meningkatkan pertumbuhan ekonomi masyarakat secara merata. Pertumbuhan ekonomi masyarakat tersebut dilakukan melalui kegiatan-kegiatan ekonomi baik itu bekerja baik sebagai PNS, pekerja di BUMN, di perusahaan swasta maupun berbisnis dengan melakukan kegiatan usaha sendiri baik melalui Badan Usaha yang berbadan hukum maupun tidak berbadan hukum. ${ }^{4}$

Seiring dengan perkembangan waktu dan perkembangan dunia usaha yang begitu pesat di negara-negara maju maupun negara berkembang, perkembangan bisnis tidak hanya berpatokan kepada bisnis saja tetapi juga pada perkembangan aturan (rule) dan hukum (law). Aturan/hukum merupakan dasar dan penopang kegiatan bisnis. Bisnis yang bersaing dan berkembang (grow) tidak terlepas dari kesadaran dan ketaatan pebisnis terhadap aturan/hukum. Hukum sebagai sarana transaksi, hukum sebagai sarana pelindung terhadap stakeholder ${ }^{5}$ yang terlibat dalam kegiatan bisnis, juga hukum sebagai sarana penyelesaian sengketaapabila terjadi masalah bisnis. Beberapa perspektif tokoh mengenai pentingnya hukum. Menurut Salomo bahwa, berbahagialah orang orang yang berpegang pada hukum, yang melakukan keadilan disegala waktu. Itu berarti, orang yang suka melawan hukum atau berbuat kejahatan hidupnya akan berujung pada duka atau derita batin di masa muda maupun tua, baik kejahatannya bisa terungkap atau tidak oleh penegak hukum. Salomo berpesan: Orang yang memelihara hukum adalah anak yang berpengertian,

\footnotetext{
${ }^{1}$ Menurut Satcipto Rahardjo, unsur-unsur perekonomian Indonesia yang terkandung dalam pasal 33 ayat 4 mencerminkan karakter dan jiwa bangsa Indonesia yang majemuk yang terdiri dari berbagai suku, ras, budaya dan bahasa dimana kesemuanya terpancar berdasarkan persatuan dan kesatuan bangsa.

${ }^{2}$ Satjipto Raharjo, Hukum Pembangunan Ekonomi, Pustaka Yustisia, Jakarta, 2008, Hal 2

${ }^{3}$ Menurut achmad irwanto sebagai juru bicara percepatan gugus covid $19 \mathrm{BNPB}$, work from home adalah bekerja dari rumah guna menghindari penyebaran dan percepatan penanggulangan covid 19 di Indonesia.

${ }^{4}$ Bismar Nasution, Diktat Kuliah Hukum Untuk Pembangunan Ekonomi, USU Press, Medan, 2019.

5 Menurut Friedmann,stakeholdersebagai kelompok atau individu yang dapat mempengaruhi dan/atau dipengaruhi oleh suatu pencapaian tujuan tertentu
} 
tetapi orang yang bergaul dengan pelahap mempermalukan ayahnya. Berpengertian berarti bijak. Jadi, sikap memelihara hukum yang benar dan baik itu bijak. Sebaliknya, kaum penjahat bukan hanya membuat dirinya malu atau hina dihadapan masyarakat tapi juga orang tuanya. ${ }^{6}$ Karena itu, setiap pebisnis harus waspada terhadap ragam bentuk penyimpangan atau kejahatan bisnisyang bisa menyeretnya ke dalam perkara hukum. Pola pikir yang perlu dibangun ialah sikap anti terhadap kejahatan. Perbuatan melawan hukum atau kejahatan dalam dunia bisnis tidak lepas dari cara pandang yang keliru terhadap bisnis itu sendiri. Business berasal dari kata "busy" dan "ness", artinya kesibukan. Jadi, apapun kesibukan manusia disebut dengan bisnis. Hanya saja ada kesibukan yang benar dan ada kesibukan yang salah, baik secara hukum maupun etika, ${ }^{7}$ Oleh karena itu seiring perkembangan zaman dan untuk memenuhi perkembangan dunia usaha yang begitu cepat terjadi, Pemerintah beserta DPR membentuk Undang-Undang nomor 40 tahun 2007 tentang Perseroan Terbatas atas perubahan undang-undang nomor 1 tahun $1995 .^{8}$

Perkembangan perekonomian suatu negara yang salah satunya didukung melalui perseroan-perseroan yang melakukan kegiatan usaha, sangat berdampak pada keputusan direksi-direksi perseoran tersebut. Keputusan tersebut dapat menguntungtungkan perseroan namun dapat juga merugikan perseroan jika direksi-direksinya bekerja dengan tidak professional apalagi mempunyai kepentingan pribadi dalam pengurusan perseroan.

Dalam menjalankan kepengurusan terhadap perseroan sepenuhnya adalah tanggungjawab Direksi. Direksi mempunyai tanggungjawab penuh atas pengelolaan perseroan. Direksi yang ditunjuk oleh pemegang saham perseroan juga bertindak mewakili perseroan baik di dalam maupun di luar pengadilan apabila perseroan tersebut berurusan dengan hukum.

Direksi sebagai pengurus dan pengelola perseroan berkewajiban mengelola perseroan dengan baik (good corporate governance) ${ }^{9}$ dengan ittikad baik dan penuh tanggung jawab sebagaimana diamanatkan oleh pasal 97 ayat Undang-Undang nomor 40 tahun 2007 tentang Perseroan Terbatas bahwa pengurusan sebagaimana pada ayat 1 wajib dilaksanakan setiap anggota direksi dengan itikad baik dan penuh tanggungjawab. ${ }^{10}$

Setiap tindakan direksi yang didasari dengan ittikad baik akan dilindungi oleh undang-undang sepanjang perbuatan tersebut dapat dibuktikan dengan cara terhindar dari perbuatan yang menguntungkan pribadi direksi dalam mengambil suatu keputusan penting terhadap perseroan yang mengakibatkan perseroan tersebut mengalami kerugian. Seorang direksi dapat dimintai pertanggungajwaban hukum secara pribadi apabila apabila dalam menjalankan kepengurusan perseroan dilakukan tidak dengan hati-hati (fiduciary duty) ${ }^{11}$ yang mengakibatkan keugian bagi perseroan. Jika dalam pengambilan keputusan terhadap perseroan, direksi telah melakukannya dengan hati-hati, berittikad baik dan penuh

\footnotetext{
${ }^{6}$ Perspektif etika dan moral, suatu hubungan yang tidak bisa dipisahkan dimana manusia harus memilikinya untuk menambah kualitas Sumber Daya Manusia serta memenuhi tujuan hukum itu sendiri yaitu Kepastian, Kemanfaatan dan Keadilan Hukum.

${ }^{7}$ Agustinus Simanjuntak, Hukum Bisnis, sebuah pemahaman integratif antara hukum dan praktik bisnis, Depok, Rajawali Pers, 2018, Hal 2.

15

${ }^{8}$ Ade Maman Suherman, Aspek Hukum dalam ekonomi global, Ghalia Indonesia, Bogor, 2005, hlm.

${ }^{9}$ Menurut Bismar Nasution, Good Corporate Governance harus dilakukan melalui unsur Pemegang Saham, Komisaris, Direksi, Manager dan Karyawan suatu Korporasi.

${ }^{10}$ Bismar Nasution, Prinsip Good Corporate Governance pada Perseroan, USU Press, Medan, 2009, hlm. 45

${ }^{11}$ Menurut Ningrum Natasya Sirait, fiduciary duty sangat penting dilakukan oleh seluruh organ perseroan guna meningkatkan produktivitas perseroan dan menghindarkan semua stakeholder dari tanggungjawab hukum.
} 


\section{PATIK : JURNAL HUKUM Vol : 10 No. 1 April 2021, Hal 1 - 14}

tanggung jawab maka direksi tersebut telah dilindungi oleh prinsip business judgement rule walau keputusan tersebut telah merugikan perusahaan.

Prinsip business judgement rule adalah suatu prinsip hukum yang berasal dari common law system dan merupakan derivatif dari hukum korporasi Amerika Serikat untuk melindungi Direksi dalam setiap pengambilan keputusan yang dilakukan dengan hati-hati, beritikad baik dan penuh tanggungjawab untuk tidak dapat dimintai pertanggungjawaban hukum baik secara pidana maupun perdata. ${ }^{12}$

\section{Tinjauan Pustaka}

Perusahaan adalah badan usaha yang modalnya terdiri dari saham-saham dan tanggung jawab dari sekutu pemegang saham terbatas yang sesuai dengan jumlah saham yang dimilikinya. Istilah perseroan pada perseroan terbatas menunjuk pada cara penentuan modal pada badan hukum itu yang terdiri dari sero-sero atau saham-saham dan istilah terbatas menunjukkan pada batas tanggung jawab para persero (pemegang saham) yang dimiliki yaitu hanya terbatas pada jumlah nilai nominal dari semua saham-saham yang dimiliki. Bentuk badan hukum ini, sebagaimana ditetapkan dalam Kitab Undang-Undang Hukum Dagang (KUHD). ${ }^{13}$

Perusahaan juga merupakan komponen bisnis yang penting dan banyak terdapat di dunia, termasuk di Indonesia yang merupakan badan hukum (legalentity) yang memiliki sifat dan ciri kualitas yang berbeda dari bentuk usaha yang lain. Salah satu ciri yang membedakan PT dengan badan usaha lainnya dapat dilihat daridoctrine of separate legal personalityyang intinya menjelaskan bahwa terdapat pemisahan kekayaan antara pemilik atau pemodal (pemegang saham) dengan kekayaan badan hukum itu sendiri.

Setiap orang dapat memiliki lebih dari satu saham yang akan menjadi bukti kepemilikan atas perusahaan tersebut. Tanggung jawab sebagai pemegang saham juga terbatas, yaitu sebanyak saham yang dimilikinya. Apabila utang perusahaan melebihi kekayaan perusahaan, maka kelebihan utang tersebut tidak menjadi tanggung jawab para pemegang saham. Apabila perusahaan mendapat keuntungan maka keuntungan tersebut dibagikan sesuai dengan jumlah kepemilikan masing-masing pemegangsaham atau ketentuan lain yang ditetapkan dalam anggaran dasar. Pemegang saham akan memperoleh bagian keuntungan yang disebut dengan dividen yang besarnya tergantung pada keuntungan yang diperoleh perseroan terbatas. ${ }^{14}$

Selain berasal dari saham, modal PT dapat pula berasal dari obligasi. Keuntungan yang diperoleh para pemilik obligasi adalah mereka mendapatkan bunga tetap tanpa menghiraukan untung atau ruginya perseroan terbatas tersebut. Pengaturan mengenai PT dalam KUHD kemudian dirumuskan dalamUndang-Undang Nomor 40Tahun 2007 yang merupakan undang-undang khusus pertama yang mengatur mengenai perseroan terbatas. Sejarah pengaturan mengenai PT sesungguhnya dimulai dari KUHD. Dalam KUHD dijelaskan bahwa badan usaha yang dapat dikatakan sebagai PT harus memiliki unsur atau ciri ciri PT yaitu Badan usaha dapat disebut sebagai PT apabila kekayaan badan usaha yang dimiliki terpisah dari kekayaan pribadi masing-masing persero (pemegang saham), yang bertujuan untuk membentuk sejumlah dana sebagai jaminan bagi perseroan, adanya persero yang tanggung jawabnya terbatas pada jumlah nominal saham yang dimilikinya dan pengurus (Direksi dan Komisaris) yang merupakan satu kesatuan pengurusan dan

\footnotetext{
${ }^{12}$ Munir Fuadi, Prinsip Business Judgement Rule, Pustaka Yustisia, Jakarta, 2008, hal 9

${ }^{13}$ Wijaya Gunawan, Seri Hukum Bisnis Perseroan Terbatas, Raja Grafindo Persada, Semarang, 2012, hal 26

${ }^{14}$ Ningrum Natasya Sirait, Jurnal Hukum Bisnis Vol XVII, USU Press, Medan, 2010, hal 34
} 


\section{PATIK : JURNAL HUKUM Vol : 10 No. 1 April 2021, Hal 1 - 14}

pengawasan terhadap perseroan tanggung jawabnya terbatas pada tugasnya yaitu harus sesuai dengan Anggaran Dasar atau keputusan RUPS.

Undang-undang nomor 40 tahun 2007 tentang Perseroan Terbatas mengatur pengertian perseroan terbatas yaitu badan hukum yang didirikan berdasarkan perjanjian, melakukan kegiatan usaha dengan modal dasar yang seluruhnya terbagi dalam saham dan memenuhi persyaratan yang ditetapkan dalam undang-undang ini serta peraturan pelaksanaannya.

Menurut M. Yahya Harahap Perseroan Terbatas atau PT adalah badan hukum yang didirikan berdasarkan perjanjian, melakukan kegiatan usaha dengan modal dasar yang seluruhnya terbagi dalam saham, dan memenuhi persyaratan yang ditetapkan dalam Undang-Undang No. 40 tahun 2007 sebagaimana telah diubah dengan serta peraturan pelaksanaannya. ${ }^{15}$

Lebih lanjut Menurut Abdulkadir Muhammad istilah "perseroan" menunjuk kepada cara menentukan modal, yaitu bagi dalam saham, dan istilah "terbatas" menunjuk kepada batas tanggung jawab pemegang saham, yaitu sebatas jumlah nominal saham yang dimiliki. Perseroan Terbatas adalah perusahaan persekutuan badan hukum. ${ }^{16}$

Dari pengertian tersebut diatas, maka dapat ditarik kesimpulan bahwa untuk dapat disebut sebagai PT menurut undang-undang harus memenuhi unsur-unsur yaitu berbentuk badan hukum, didirikan atas dasar perjanjian, melakukan kegiatan usaha, modalnya terbagi atas saham yang kesemua unsur-unsurnya tidak bisa terpisahkan.

Pada umumnya orang berpendapat bahwa PT adalah suatu bentuk perseroan yang didirikan untuk menjalankan suatu perusahaan dengan modal perseroan tertentu yang berbagi atas saham-saham dimana para pemegang saham ikut serta dengan mengambil satu saham atau lebih dan melakukan perbuatan-perbuatan hukum dibuat atas nama bersama dengan tidak bertanggung jawab sendiri untuk persetujuan-persetujuan perseroan itu dengan tanggung jawab yang semata-mata terbatas pada modal yang mereka setorkan.

Bertolak dari beberapa nilai lebih yang melekat pada PT yaitu bahwa PT pada umumnya mempunyai kemampuan untuk mengembangkan diri, mampu mengadakan kapitalisasi modal dan sebagai wahana yang potensial untuk memperoleh keuntungan baik bagi institusinya sendiri maupun bagi para pendukungnya (pemegang saham/investor), oleh karena itu bentuk badan usaha ini (PT) sangat diminati olehmasyarakat. Jadi PT sebagai badan hukum, terutama sebagai badan hukum yang mampu dimanfaatkan untuk memperoleh keuntungan ekonomi mempunyai nilai lebih apabila dibandingkan dengan badan usaha lain, baik ditinjau dari aspek ekonomi maupun aspek yuridis.

Prinsip Business Judgment Rule adalah suatu prinsip hukum yang berasal dari system common law ${ }^{17}$ dan merupakan derivative dari Hukum Korporasi di Amerika Serikat. Konsep ini mencegah pengadilan-pengadilan di Amerika Serikat untuk mempertanyakan pengambilan keputusan usaha oleh Direksi, yang diambil dengan itikad baik.

Dasar pertimbangan adanya prinsip Business Judgment Rule yaitu bahwa tidak setiap keputusan direksi dapat memberikan keuntungan bagi perseroan, seperti lazimnya dalam dunia usaha ada untung dan ada rugi. Walaupun begitu, direksi dalam mengambil keputusannya atau melakukan tindakan lainnya mendasarkannya hanya untuk kepentingan perseroan (tidak ada kepentingan pribadi) dengan kehati-hatian dan dengan itikad baik.

\footnotetext{
${ }^{15}$ M. Yahya Harahap, Hukum Perseroan Terbatas, Sinar Grafika, Jakarta, 2011, hal 3

${ }^{16}$ Abdulkadir Muhammad, Hukum Perusahaan, Citra Adytia, Bandung, 2015, hal 5

17 Simamora, Janpatar., Tafsir Makna Negara Hukum dalam Perspektif Undang-Undang Dasar
} Negara Republik Indonesia Tahun 1945, Jurnal Dinamika Hukum FH Universitas Jenderal Soedirman, Vol. 14 No. 3 September 2014, hlm. 547-561 


\section{PATIK : JURNAL HUKUM Vol : 10 No. 1 April 2021, Hal 1 - 14}

Menurut pengertian yang diberikan Black's Law Dictionary dapat diketahui bahwa business judgment rule melindungi direksi atas setiap keputusan bisnis yang merupakan transaksi perseroan, selama hal tersebut dilakukan dalam batas-batas kewenangan dengan penuh kehati-hatian dan itikad baik. ${ }^{18}$

Menurut Sutan Remi Syahdeni, dapat diartikan business judgement rule adalah salah satu prinsip dari pengelolaan perusahaan yang telah menjadi bagian dari common law system sekitar tahun 1950. Business judgement rule ini melindungi direksi dari tugas dan tanggungjawab yang dipikulnya. Jika direksi tersebut berhak atas perlindungan hukum maka pengadilan tidak berhak mencampuri atas putusan yang diambilnya tersebut, namun sebaliknya jika tidak berhak atas perlindungan hukum atas putusan yang telah diambilnya maka pengadilan wajib memeriksa putusan tersebut apakah terdapat kejujuran yang mendasar dan ittikad baik kepada perusahaan dan pemegang saham minoritas serta harus dilakukan tanpa self fialing, tidak dilakukan untuk kepentingan pribadi dan harus dengan ittikad baik. $^{19}$

Prinsip business judgement rule juga menjaga dan melindungi agar direksi dari gugatan yang dilakukan oleh siapa pun asalkan direksi tersebut dapat dalam mengambil suatu keputusan sudah dilakukan dengan kejujuran dan berhati-hati. Hal tersebut juga harus didasarkan pada atas data, pendapat, laporan dan hal yang dapat membuktikan pengambilan keputusan oleh direksi tersebut sudah tepat.

Perlu untuk mengetahui bagaimana prinsip business judgement rule ini digunakan. prinsip business judgement rule ini sering $\mathrm{x}$ ditafsirkan berbeda bila diterapkan pada kasus - kasus seperti ini :

a. Adanya business judgement rule yang lebih persuasif, dalam hal ini pengadilan bukan hanya menerapkan business judgement rule, akan tetapi menjadikan aplikasi primernya.

b. Jika terlihat adanya kepentingan pribadi dari direksi/pengurus terhadap masalah yang lebih berfokus dari motif suatu tindakan akan tetapi pengadilan masih tetap menerapkan prinsip business judgement rule.

c. Adanya kepentingan pribadi dari direktur/pengurus, dalam hal ini biasanya business judgement rule tidak diterapkan.

d. Jika keputusan bisnis bertentangan dengan policy atau aturan tertentu dari pemerintah, terhadap kasus ini business judgement rule tidak dapat diterapkan bahkan dapat dikatakan diektur melanggar fiduciary duty terhadap perusahaan. ${ }^{20}$

Menurut Bismar Nasution bahwa perusahaan diumpamakan sebuah kapal dimana direktur adalah seorang nahkoda. Baik buruknya perjalanan nahkoda tersebut sangatlah tergantung kepada kemampuan nahkoda untuk mengemudikan kapal tersebut. Demikian juga dengan perusahaan, baik buruknya perusahaan tersebut adalah sangat tergantung pada kebijakan yang akan dicapai seorang direksi perusahaan tersebut.

Mengenai syarat berlakunya prinsip business judgement rule, Bismar Nasution sependapat dengan pendapat umum bahwa seorang direktur tidak dapat dihukum oleh karena kebijakan yang diambilnya jika (1) dengan ittikad baik, (2) dengan dasar yang kuat, (3) tidak mengandung konflik kepentingan ${ }^{21}$

\footnotetext{
${ }^{18}$ Ningrum Natasya Sirait, Penerapan Business Judgement Rule pada Direksi, Jurnal Hukum, USU Press, Medan, 2009, hal 37

${ }^{19}$ Sutan Remi Syahdeni, Tanggung Jawab Direksi dan Komisaris, Pustaka Yustisia, Jakarta, 2011, hal 78

${ }^{20}$ Ningrum Natasya Sirait, Hukum Kontrak Bisnis, USU Press, Medan, 2017, hal 60

${ }^{21}$ Bismar Nasution, Ibid hal 89
} 


\section{PATIK : JURNAL HUKUM Vol : 10 No. 1 April 2021, Hal 1 - 14}

Dengan demikian seorang pengurus pada umumnya direksi dalam perseroan terbatas maupun badan usaha lainnya tidak dapat dimintai pertanggungjawaban hukum baik dipidana maupun digugat secara perdata oleh siapa pun termasuk pemegang saham jika direksi tersebut menjalankan fungsi perusahaan sesuai tujuan perusahaan dan AD/ART dengan hati-hati dan penuh tanggungjawab. Direksi atau Direktur adalah suatu organ Perseroan yang memiliki tugas, kewenangan dan tanggungjawab yang penuh terhadap pengurusan dan jalannya Perseroanyang dipimpinnya untuk kepentingan dan tujuan Perseroantersebut. Direksi juga mewakili dan bertindak untuk dan atas nama Perseroandi dalam maupun di luar pengadilan sesuai dengan perundang-undangan yang berlaku dan ketentuan dalam anggaran dasar dari Perseroan tersebut.

Pada dasarnyaDireksimerupakan organ yang mengurus kegiatan Perseroan. Oleh karena itu setiap Perseroan Terbatas wajib memiliki Direksiminimal 1 orang. Akan tetapi, untuk beberapa jenis Perseroanwajib memiliki minimal 2 (dua) orang Direksi, yakni yang merupakan Perseroanyang menghimpun dan/atau mengelola dana masyarakat, Perseroan yang menerbitkan surat pengakuan utang kepada masyarakat dan Perseroan merupakan Perseroan terbuka. Jika memang dalam hal Perseroan memiliki lebih ari satu orang Direktur atau Direksi, maka salah satu anggotaDirekturnya diangkat sebagai Direktur utama (Presiden Direktur). ${ }^{22}$

Meskipun masa jabatan keanggotaan masing-masing anggotaDireksitelah ditentukan dalam anggaran dasar Perseroan, namun ketentuan tersebut tidaklah membatasi hak dari pemegang saham untuk setiap saat memberhentikan salah satu atau lebih anggotaDireksisebelum berakhirnya masa jabatan yang ditentukan dalam anggaran dasar Perseroan baik dengan mengangkat penggantinya yang baru maupun dengan hanya memberhentikan keanggotaan Direksi yang bersangkutan saja selama dan sepanjang syarat minimum jumlah anggotaDireksisebagaimana ditentukan dalam anggaran dasar maupun peraturan perundang-undangan lain yang berlaku tetap dipertahankan. Keputusan RUPS tersebut hanya dapat diambil setelah anggotaDireksiyang hendak diberhentikan tersebut diberikan kesempatan untuk membela diri maupun menyatakan pendapatnya dalam RUPS tersebut. Ruang lingkup kewenangan direksi dalam pengurusan perseroan yang diamanatkan oleh UUPT No. 40 Tahun 2007 sangatlah luas dan menunjukkan ciri suatu sistem. Sistem yang digunakan untuk menunjukkan pengertian skema atau metode pengaturan organisasi atau susunan sesuatu metode tata cara.

Adapun kewenangan direksi perseroan demi hukum berakhir dengan dipailitkannya perseroan tersebut, dimana kewenangan direksi tersebut beralih kepada kurator sepanjang kewenangan direksi berkaitan dengan pengurusan dan perbuatan pemilikan harta kekayaan perseroan pailit. Agar direksi sebagai organ perseroan yang mengurus perseroan seharihari dapat mencapai prestasi terbesar untuk kepentingan perseroan, maka ia harus diberi kewenangan-kewenangan tertentu untuk mencapai hasil yang optimal dalam mengurus perseroan. $^{23}$

Dari kewenangan yang diberikan, direksi perlu diberi tanggung jawab untuk mengurus perseroan. Hal ini berarti dalam membicarakan kewenangan direksi diperlukan pemahaman tentang tanggung jawab. Mengenai kewenangan direksi sebagaimana ketentuan ayat (3), direksi mewakili perseroan adalah tidak terbatas dan tidak bersyarat, kecuali ditentukan lain dalam undang-undang dan Anggaran Dasar atau keputusan RUPS.

Adapun kewenangan direksi perseroan demi hukum berakhir dengan dipailitkannya perseroan tersebut dimana kewenangan direksi tersebut beralih kepada kurator sepanjang

${ }^{22}$ Immanuel Rivanda S, Jurnal Hukum Bisnis, USU Press, Medan, hal 20

${ }^{23}$ Ahmad Yani, Seri hukum bisnis dan perseroan terbatas, Raja Grafindo Persada, Jakarta, 2006, hal 


\section{PATIK : JURNAL HUKUM Vol : 10 No. 1 April 2021, Hal 1 - 14}

kewenangan direksi berkaitan dengan pengurusan dan perbuatan pemilikan harta kekayaan perseroan pailit. Agar direksi sebagai organ perseroan yang mengurus perseroan seharihari dapat mencapai prestasi terbesar untuk kepentingan perseroan, maka direksi harus diberi kewenangan-kewenangan tertentu untuk mencapai hasil yang optimal dalam mengurus perseroan. Dari kewenangan yang diberikan, ia perlu diberi tanggung jawab untuk mengurus perseroan. Hal ini berarti dalam membicarakan kewenangan direksi, diperlukan pemahaman tentang tanggung jawab.

\section{Metode}

Ruang lingkup Penelitian adalah batasan-batasan yang membatasi kegiatan dalam penelitian, yang dalam hal ini adalah menjelaskan tentang batasan-batasan yang akan diteliti. ${ }^{24}$ Adapun ruang lingkup penelitian ini adalah (1) Bagaimana Penerapan prinsip business judgement rule terhadap direksi yang melakukan kebijakan yang merugikan perusahaan, dan (2) Bagaimana Perlindungan hukum terhadap direksi yang melakukan kebijakan dengan prinsip business judgement rule yang merugikan perusahaan. Adapun Jenis Penelitian ini adalah Penelitian Hukum Normatif yaitu jenis Penelitian yang hanya bersumber pada Putusan Pengadilan dan Undang-Undang.

Suatu Penelitian Hukum dimulai dengan Melakukan Suatu Pendekatan Terhadap Bahan-Bahan Hukum Sebagai Dasar Dalam Melakukan Penelitian Hukum Terhadap Kasus-Kasus Hukum yang Konkret. ${ }^{25}$ Adapun Metode Pendekatan Penelitian ini adalah Penelitian Yuridis Normatif yaitu Jenis Pendekatan yang hanya bersumber pada BahanBahan Hukum dan peraturan perundang-undangan. Bahan-bahan Dalam Penelitian ini Bersumber dari :

1. Bahan Hukum Primer Berupa Kitab Undang-Undang Hukum Perdata dan Kitab Undang-Undang Hukum Bisnis.

2. Bahan Hukum Sekunder Berupa Undang-Undang Nomor 40 Tahun 2007 Tentang Perseroan Terbatas dan Undang-Undang nomor 19 tahun 2003 tentang BUMN.

3. Bahan Hukum Tersier Berupa Kamus Hukum, Jurnal, Majalah dan Referensi dari Akses Internet sebagai bahan Pelengkap

Analisis data yang digunakan dalam penelitian ini adalah analisis data yuridis deskriftif yaitu menggambarkan kenyataan-kenyataan yang ada dalam masyarakat dikaitkan dengan peraturan perundang-undangan yang berlaku saat ini.

\section{Pembahasan Dan Hasil}

Setiap pengambilan keputusan, direksi harus menempatkan diri untuk dan atas nama perseroan. Maka konsekuensi baik buruknya segala sesuatu yang dibuatnya pada prinsipnya dipikul perseroan itu sendiri. Prinsip itu sendiri berlaku dalam common law system maupun civil law system. Namun prinsip itu bukanlah prinsip yang baku karena dalam hal-hal tertentu konsekuensi dan tindakan direktur ini harus dipikul secara pribadi oleh direktur sendiri walaupun kenyataannya dia bertindak untuk dan atas nama perseroan. ${ }^{26}$

Prinsip Business Judgement Rule adalah salah satu doktrin yang ada dalam hukum perusahaan yang memberikan perlidungan terhadap direksi perusahaan untuk tidak bertanggungjawab atas kerugian yang timbul dari suatu konsekuensi apabila tindakan

${ }^{24}$ Abdurrahman, Metode Penelitian Hukum, Erlangga, Semarang, 2011, hal 63

${ }^{25}$ Abdurrahman, Ops cit. Hal 77

${ }^{26}$ Purwosutjipto, Pokok Hukum DagangIndonesia, Djambatan, Jakarta, 2001, hal 90 


\section{PATIK : JURNAL HUKUM Vol : 10 No. 1 April 2021, Hal 1 - 14}

direksi didasarkan atas ittikad baik dan penuh kehati-hatian. Prinsip ini sebagai perlindungan hukum terhadap pengurus perusahaan terutama direksi yang beritikad baik.

Menurut Ningrum Natasya Sirait, Prinsip Business Judgement Rule merupakan doktrin yang mengajarkan bahwa keputusan direksi mengenai aktivitas perseroan tidak dapat langsung dipersalahkan oleh siapa pun meski keputusan tersebut merugikan perseroan. Adapun ketentuan-ketentuan yang harus dipenuhi direksi yaitu dilakukan dengan ittikad baik, dilakukan dengan tujuan yang benar (proper purpose), dilakukan dengan kehati-hatian (due care) serta dilakukan dengan cara yang layak dipercayai (reasonable belief) untuk yang terbaik bagi perusahaan. ${ }^{27}$

Mulanya business judgment rule merupakan doktrin yang berasal dari sistem common law dan merupakan derivatif dari Hukum Perusahaan di Amerika Serikat sebagai upaya untukmencegah pengadilan-pengadilan di Amerika Serikat mempertanyakan pengambilan keputusanbisnis oleh direksi.

Menurut hukum di Amerika serikat direktur akan bertanggungjawab secara pribadi jika dia menjalankan tugasnya tidak sesuai dengan standar tertentu, misalnya dengan sengaja menyalahgunakan dan menyelewengkan dana perusahaan. Tindakan untuk mengisukan saham sebagai saham untuk disetor penuh padahal secara faktual saham tersebut belum disetor sama sekali juga merupakan bertentangan dengan standar yang baik.

Ada beberapa kasus di Amerika Serikat yang menjadi dasar business judgment rule diantaranya adalah kasus yang dijadikan pertimbangan oleh Delaware Supreme Court yang menyatakan bahwa business judgment rule melibatkan 2 (dua) hal yaitu proses dan substansi. Sebagai proses, business judgment rule melibatkan formalitas pengambilan keputusan dalam perseroan sedangkan sebagai subtansi, business judgment rule tidak dapat diberlakukan dalam suatu transaksi. haruslah dapat dibuktikan bahwa tindakan tersebut secara subtansi tidakmemberikan manfaat bagi perseroan. Dalam kasus yang lain Grobow v. Perot dijelaskan bahwaagar terlaksana business judgement rule direksi memperhatikan itikad baik, memberikanpertimbangan terbaik bagi perusahaan serta melakukan penelaahan berdasarkan loyalitas terhadapperusahaan. ${ }^{28}$

Sistem hukum di Indonesia tidak mengenal pranata "fidusia relations" sehingga hubungan perusahaan dan direktur bukanlah hubungan antara "trustee" dan "beneficiary" seperti dalam common law system. Dalam sistem hukum Indonesia hubungan tersebut hanya hubungan antara pemberi kuasa (perusahaan) dan penerima kuasa (direktur) atau apabila direktur diberi upah maka secara legal hubungan tersebut merupakan jasa hubungan perburuhan.

Namun, bagi negara-negara civil law system yang sumber hukum terletak pada peraturan perundang-undangan, maka pengadilan bertugas untuk melakukan interpretasi terhadap doktrintersebut yang disebabkan oleh belum adanya pengaturan yang secara komprehensif, jelas danspesifik mengenai business judgment rule. Business judgment rule timbul sebagai akibat telahdilaksanakannya kewajiban sebagai direksi dengan penuh tanggungjawab (fiduciary duty) oleh seorang direksi, yang didalamnya termasuk pelaksanaan atas duty of skill and care. ${ }^{29}$

Selanjutnya dalam hukum Indonesia seorang direksi akan bertanggungjawab secara hukum atas tindakan yang dilakukan dewan direksi atau oleh perusahaan. Peran direksi biasanya beriringan dengan tugas, keberadaan, kewenangan, hak dan kewajiban yang melekat pada diri seorang direksi termasuk yang melekat pada teori dan prinsip hukum.

\footnotetext{
${ }^{27}$ Ningrum Natasya Sirait, Diktat Kuliah Hukum Bisnis, USU Press, Medan, 2018, hal 201

${ }^{28}$ Notarius, Business Judgement Rule Sebagai Imunity Bagi Direksi BUMN di Indonsia, Jurnal Hukum Bisnis, Edisi VIII, No. 2, September 2015.

${ }^{29}$ Ningrum Natasya Sirait, Ops Cit hal 190
} 


\section{PATIK : JURNAL HUKUM Vol : 10 No. 1 April 2021, Hal 1 - 14}

Prinsip business judgement rule juga telah diakomodir dalam UUPerseroan Terbatas nomor 40 tahun 1997 pada Pasal 97 ayat (5) disebutkan bahwa seorang Direksi bebas dari tanggung jawab atas kerugian perseroan apabila dapat membuktikan :

a. Kerugian tersebut bukan karena kelalaian dan kesalahannya

b. Telah melakukan pengurusan dengan ittikad baik sesuai dengan maksud dan tujuan perseroan

c. Tidak mempunyai benturan kepentingan baik langsung maupun tidak langsung atas tindakan pengurusan yang mengakibatkan kerugian

d. Telah mengambil tindakan untuk mencegah timbul atau berlanjutnya kerugian tersebut. ${ }^{30}$

Menurut Bismar Nasution, pada umumnya business judgement rule hanya berlaku pada keputusan bisnis saja. Dalam UU No. 40 tahun 2007 tentang Perseroan Terbatas, prinsip ini hanya berlaku pada pengurusan perseroan yang merupakan aspek yang lebih luas dibandingkan dengan keputusan bisnis. Hal ini berarti direksi dapat dibebaskan dari tanggungjawabnya bukan hanya dalam hal keputusan bisnia yang dia ambil tetapi juga dalam aspek management perusahaan juga direksi dapat membuktikan kelima unsur diatas. $^{31}$

Undang - undang Perseroan Terbatas tidak menjelaskan ukuran apa yang dipakai sehingga seorang direksi dapat digolongkan telah melakukan kesalahan dan kelalaian. Untuk dapat melakukan pendepatan yang lebih terarah, perlu dipahami arti kata "kesalahan" dan "kelalaian" dan ukuran yang dipakai sebagai tolak ukur untuk menilai apakah kebijakan direksi tergolong salah atau lalai.

Sebagaimana diketahui bahwa pasal 136 KUH Perdata mensyaratkan adanya unsur kesalahan (schuld) terhadap suatu perbuatan melawan hukum. Sudah merupakan tafsiran umum dalam ilmu hukum bahwa unsur kesalahan tersebut dianggap ada jika memenuhi salah satu diantara 3 (tiga) syarat yaitu ada unsur kesengajaan, ada unsur kelalaian (negligence, culpa) dan Tidak ada alasan pemaaf (rechtvaardigings-grond), atau keadaan overmacht, membela diri, tidak waras, dan lain-lain. ${ }^{32}$

Ditinjau dari segi berat ringannya derajat kesalahan dari pelaku perbuatan melawan hukum, maka dibandingkan dengan perbuatan melawan hukum yang dilakukan denganunsur kelalaian, maka perbuatan melawan hukum yang dilakukan dengan unsur kesengajaan derajat kesalahannya lebih tinggi. Jika seseorang yang dengan sengaja merugikan orang lain (baik untuk kepentingannya sendiri atau bukan), berarti dia telah melakukan perbuatan yang melanggar hukum tersebut dalam arti yang sangat serius ketimbang dilakukannya hanya sekedar kelalaian belaka.

Dengan tidak adanya kejelasan definisi mengenai kesalahan dan kelalaian akan mengakibatkan sangat sulit untuk membuktikan bahwa tidak ada unsur kesalahan atau kelalaian dalam keputusan bisnis atau kepengurusan tanpa parameter yang jelas tentang apa yang dapt dikategorikan sebagai kesalahan atau kelalaian. Dalam struktur perusahaan yang semakin rumit tidak jarang Direksi mendelegasikan kewenangannya kepada bawahannya yang mungkin menyalahgunakan kewenangan tersebut. Hal yang sama terjadi dalam hal keputusan bisnis. Dalam iklim usaha yang semakin kompetitif, tidak jarang Direksi harus mengambil keputusan yang bersifat spekulatif untuk dapat bersaing dengan

\footnotetext{
${ }^{30}$ Pasal 95 ayat 7 Undang-Undang Nomor 40 Tahun 2007 Perseroan Terbatas

${ }^{31}$ Bismar Nasution, Ops Cit hal 78

${ }^{32}$ Sutan Remi Syahdeni, Ibid hal 27
} 


\section{PATIK : JURNAL HUKUM Vol : 10 No. 1 April 2021, Hal 1 - 14}

kompetitornya. Apakah apabila nantinya keputusan tersebut mengakibatkan kerugian, Direksi dapat dianggap salah atau lalai.

Dari definisi diatas bahwa dibalik kesalahan dan kelalaian terkandung pengertian adanya perbuatan melawan hukum. Perbuatan melawan hukum ditafsirkan secara luas mengingat begitu banyak peraturan-peraturan yang ada. Ada beberapa ketentuan yang harus dipedomani direksi dalam menjalankan tugasnya antara lain sebagai berikut :

a. Undang-undang yang berlaku serta ketentuan yang berada dibawahnya

b. Anggaran Dasar perusahaan. Dalam AD/ART biasanya tercantum hak, kewajiban, wewenang serta visi dan misi perusahaan

c. Standar operasional prosedur (SOP) yang mengatur langkah-langkah yanh harus dijalankan dalam memproses suatu pekerjaan dari awal hingga pekerjaan selesai.

d. Kesepakatan-kesepakatan yang sudah diratifikasi baik bilateral maupun multilateral

e. Kelaziman yang biasanya diakui dan berlaku sebagai best practice. ${ }^{33}$

Setiap aspek diatas harus dituangkan dalam pedoman perusahaan dan setiap person pada perusahaan termasuk direksi wajib mempedomaninya. Dengan demikian setiap keputusan atau kebijakan Direksi dapat dipertanggungjawabkan dengan memakai buku pedoman tersebut. buku pedoman yang tidak mengakomodir aspek - aspek tersebut, maka hal itu menjadi tanggung jawab Direksi dan dapat dikategorikan sebagai kesalahan atau kelalaian Direksi. Jika akibat hal tersebut perusahaan mengalami kerugian, business judgement rule tidak berlaku.

Menurut Bismar Nasution dengan mengutip Dine, menyatakan bahwa untuk menghindari unsur kesalahan dan kelalaian dan menjamin terpenuhinya unsur kehatihatian dalam keputusannya, seorang Direksi harus :

a. Mendapat informasi yang cukup mengenai kebijakan pengurusan atau keputusan yang akan diambil

b. Agenda dan dokumen pendukung mengenai aspek-aspek kepengurusan dan keputusan bisnisnya harus tersedia dalam proses pengambilan keputusan.

c. Mengungkapkan pernyataan-pernyataan yang tidak memihak dalam proses pengambilan keputusan.

d. Membuat catatan dan dokumen tentang partisipasi mereka dalam proses pengambilan keputusan.

e. Membentuk sebuah komite untuk menjamin hal-hal penting yang berkaitan dengan keputusan yang akan diambil telah diperiksa oleh ahli di bidang tersebut dalam hal yang tidak dapat dipahami dan ditangani oleh management. ${ }^{34}$

Teori beralihnya beban tanggung jawab perseroan kepada Direksi ini dikenal dengan istilah doktrin "piercing the corporate veil". dalam bahasa Indonesia, "piercing" dapat diartikan sebagai menembus, menusuk, atau menerobos, sedangkan "veil" dapat diartikan sebagai kerudung, selubung, atau tirai. "Piercing the corporate veil" dapat diartikan secara harfiah adalah menembus selubung perseroan yang oleh sebagian orang juga diartikan sebagai "lifting the corporate veil" atau membuka tabir perseroan. 35

Ditembusnya selubung perseroan atau diterapkannya doktrin Piercing the Corporate Veil, dapat dilakukan dalam hal terjadinya gugatan terhadap Direksi yang dianggap telah merugikan perseroan karena adanya pelanggaran atas fiduciary duty, duty of skill dan duty of care serta statutory duties yaitu kewajiban untuk bertindak menurut peraturan perundang-undangan yang berlaku. Memang pada prinsipnya dan secara klasik, dengan diterapkannya teori piercing the corporate veil, maka pihak pemegang sahamlah

\footnotetext{
${ }^{33}$ Kartini Mulyadi, Prinsip-Prinsip Hukum Umum Perusahaan, Alumni, Bandung, 2009, hal 71

${ }^{34}$ Bismar Nasution, Ibid hal 103

${ }^{35}$ Munir Fuadi, Ops Cit hal 60
} 


\section{PATIK : JURNAL HUKUM Vol : 10 No. 1 April 2021, Hal 1 - 14}

yang biasanya dimintai tanggung jawab atas kegiatan yang dilakukan oleh perseroan. Akan tetapi, dalam perkembangannya kemudian, dari penerapan teori piercing the corporate veil tersebut beban tanggung jawab dipindahkan juga dari perseroan kepada pihak lainnya selain pemegang saham yaitu kepada direksi. Jika doktrin Piercing of Corporate Veil terlihat cenderung membebani Direksi dengan pertanggungjawaban secara pribadi, maka doktrin Business Judgement Rule adalah alat bagi Direksi untuk melindungi dirinya dari pertanggungjawaban secara pribadi.

Dalam bahasa Indonesia dapat diartikan bahwa doktrin Business Judgement Rule adalah sebuah anggapan bahwa dalam membuat keputusan bisnis yang tidak mengandung kepentingan pribadi atau keuntungan pribadi secara langsung. direksi perseroan bertindak dengan dasar informasi yang cukup dengan itikad baik dan dengan keyakinan yang jujur bahwa tindakannya adalah bagi kepentingan terbaik perseroan. Kaidah ini melindungi Direksi dan pejabat perseroan dari pertanggungjawaban atas transaksi yang tidak menguntungkan atau merugikan perseroan apabila transaksi tersebut dilakukan dengan itikad baik, penuh kehatihatian dan dalam lingkup kewenangan Direksi atau pejabat yang bersangkutan. ${ }^{36}$

Di sisi lain, doktrin Business Judgement Ruledalam hukum perseroan Indonesia dapat ditemukan dalam Pasal 97 ayat 5 Jo. Pasal 104 ayat 4 UU No. 40 tahun 2007 tentang Perseroan Terbatas yang memberikan pengecualian atas pertanggungjawaban anggota direksi secara pribadi dalam terjadinya kerugian atau kepailitan, apabila dirinya dapat membuktikan bahwa kerugian tersebut bukan karena kesalahan atau kelalaiannya, telah melakukan pengurusan dengan itikad baik dan kehati-hatian untuk kepentingan dan sesuai dengan maksud dan tujuan Perseroan, tidak mempunyai benturan kepentingan baiklangsung maupun tidak langsung atas tindakan pengurusan yang mengakibatkan kerugian dan telah mengambil tindakan untuk mencegah timbul atau berlanjutnya kerugian tersebut.

\section{Kesimpulan Dan Saran}

Penerapan prinsip Business Judgement Rule terhadap direksi yang melakukan kebijakan yang merugikan perusahaan di Indonesia belumlah maksimal. Minimnya sumber daya manusia penegak hukum kita terutama kejaksaan berpeluang menyeret direksi yang melakukan tugasnya berdasarkan prinsip ittikad baik, kehati-hatian dan tanggung jawab ke ranah pidana jika perusahaan yang dia pimpin adalah Perusahaan BUMN (Persero). Perlindungan Terhadap Direksi yang melakukan kebijakan yang merugikan perusahaan sangatlah minim di Indonesia. Tidak adanya tolak ukur ittikad baik menjadi momok yang dapat disalahgunakan penegak hukum untuk menyeret direksi ke ranah hukum.

Pemilik perusahaan yaitu pemegang saham dan penegak hukum harus lebih hatihati dan cerdas dalam menjatuhkan kesalahan kepada direksi terkait kepengurusan direksi dalam menjalankan perusahaan agar penerapan prinsip business judgement rule terhadap direksi yang melakukan pengurusan perusahaan dengan hati-hati, ittikad baik dan bertanggungjawab bisa berjalan dengan baik. Saran saya kepada pembentuk undangundang yaitu Pemerintah Indonesia dan Lembaga Legislatif agar membuat turunan undang-undang nomor 40 tahun 2007 tentang Perseroan Terbatas yang mengatur lebih jelas dan detail tentang prinsip business judgement rule. Turunan tersebut dapat berupa Peraturan Pemerintah dan Peraturan Menteri Hukum \& HAM sehingga timbulnya kepastian hukum dan perlindungan hukum bagi Direksi dalam menjalankan perseroan.

\footnotetext{
${ }^{36}$ Simon Santoso, Business Judgement Rule Sebagai Perlidungan Hukum Terhadap Direksi, Jurnal Hukum Bisnis, September 2016, hal 29
} 


\section{PATIK : JURNAL HUKUM Vol : 10 No. 1 April 2021, Hal 1 - 14}

\section{DAFTAR PUSTAKA}

\section{BUKU}

Abdurrahman, Metode Penelitian Hukum, Erlangga, Semarang, 2011.

Abdulkadir Muhammad, Hukum Perusahaan, Citra Adytia, Bandung, 2015.

Ade Maman Suherman, Aspek Hukum dalam ekonomi global, Ghalia Indonesia, Bogor, 2005.

Fuadi, Munir, Prinsip Business Judgement Rule, Pustaka Yustisia, Jakarta, 2008

Fred G. Tumbuan, Tanggungjawab direksi perseroan, Alumni, Bandung, 2006.

Harahap, M.Yahya, Pengantar Hukum Perseroan Terbatas, Citra Adytia Bakti, Jakarta, 2009

Gunawan widjaya, Tanggungjawab direksi atas kepailitan pereroan, Raja Grafindo Persada, Jakarta, 2003.

Gunawan, Gunawan, Seri Hukum Bisnis Perseroan Terbatas, Raja Grafindo Persada, Semarang, 2012.

Ginting, Jamin, Hukum Perseroan Terbatas, Erlangga, 2007, Jakarta,

Harahap, M.Yahya, Hukum Perseroan Terbatas, Sinar Grafika, Jakarta, 2011.

Harahap, M.Yahya, Perlindungan Hukum Terhadap Direksi Korporasi, Sinar Grafika, Jakarta, 2009

Kartini Mulyadi, Prinsip-Prinsip Hukum Umum Perusahaan, Alumni, Bandung, 2009

Nasution, Bismar, Diktat Kuliah Hukum Untuk Pembangunan Ekonomi, USU Press, Medan, 2019.

Nasution, Bismar,Pengantar Hukum Perseroan Terbatas, Pustaka Yustisia, Jakarta, 2012

Nasution, Bismar, Prinsip Good Corporate Governance pada Perseroan, USU Press, Medan, 2009

Nasution Bismar, Penerapan Prinsip Judgement Rule pada Perseroan Indonesia, Refika Aditama, Jakarta, 2011.

Nindyo Pramono, Perlindungan Hukum Terhadap Direksi Perseroan Terbatas, Raja Grafindo, Bandung, 2015.

Ratna Siswosoediro, Buku Pintar Pengurusan Izin, Visimedia, Jakarta, 2009.

Raharjo, Satcipto, Hukum Pembangunan Ekonomi, Pustaka Yustisia, Jakarta, 2008.

Simatupang, Richard Buton, Aspek Hukum Dalam Bisnis, Rineka Cipta, Jakarta, 2009.

Sirait, Natasya Ningrum, Diktat Kuliah Hukum Bisnis, USU Press, Medan, 2019.

Simanjuntak, Agustinus, Hukum Bisnis, sebuah pemahaman integratif antara hukum dan praktik bisnis, Depok, Rajawali Pers, 2018.

Syahdeni, Sutan Remi, Tanggung Jawab Direksi dan Komisaris, Pustaka Yustisia, Jakarta, 2011.

Sirait, Natasya Ningrum, Hukum Kontrak Bisnis, USU Press, Medan, 2017.

Purwosutjipto, Pokok Hukum Dagang Indonesia, Djambatan, Jakarta, 2001.

Yani, Ahmad,Seri hukum bisnis dan perseroan terbatas, Raja Grafindo Persada, Jakarta, 2006.

\section{Jurnal}

Anggusti, Martono, Dina Mayasari Sinaga, and Janpatar Simamora. 2021. "PENGGUNAAN INDIRECT EVIDENCE (ALAT BUKTI TINDAK LANGSUNG) OLEH KPPU DALAM PROSES PEMBUKTIAN DUGAAN PRAKTIK KARTEL (STUDI DI KANTOR KOMISI PENGAWAS 
PATIK : JURNAL HUKUM Vol : 10 No. 1 April 2021, Hal 1 - 14

PERSAINGAN USAHA WILAYAH I MEDAN)". Nommensen Journal of Legal Opinion 2 (01):37-46. https://doi.org/10.51622/njlo.v2i01.207.

Chatamarrasjid, Fiduciary Duty Sebagai Standar Para Direksi Dalam Melaksanakan Tugasnya, Jurnal Hukum dan Pembangunan, Juni 2012.

Immanuel Rivanda S, Jurnal Hukum Bisnis, USU Press, Agustus 2018.

Gideon Paskha Wardana, Jurnal Hukum Business Judgement Rule Sebagai Perlindungan Atas Pertanggungjawaban Direksi Perseroan,UI Press, Jakarta, 2012.

Nababan, R., Anggusti, M., \& Sirait, S. L. (2021). PERLINDUNGAN HUKUM TERHADAP KONSUMEN YANG MENGALAMI KERUGIAN AKIBAT PENGIRIMAN BARANG OLEH PERUSAHAAN EKSPEDISI LAUT MENURUT UNDANG-UNDANG NOMOR 8 TAHUN 1999 TENTANG PERLINDUNGAN KONSUMEN. Nommensen Journal of Legal Opinion, 2(01), 12-23. https://doi.org/10.51622/njlo.v2i01.206

Ningrum Natasya Sirait, Penerapan Business Judgement Rule pada Direksi, Jurnal Hukum, USU Press, Medan, 2009.

Ningrum Natasya Sirait, Jurnal Hukum Bisnis Vol XVII, USU Press, Medan, 2010.

Simamora, Janpatar., Tafsir Makna Negara Hukum dalam Perspektif Undang-Undang Dasar Negara Republik Indonesia Tahun 1945, Jurnal Dinamika Hukum FH Universitas Jenderal Soedirman, Vol. 14 No. 3 September 2014. 